\title{
Path Analysis of Work Passion Model of Thai Teachers in Municipal Schools
}

\author{
Saitib Lautongmeesakun and Sageemas Na Wichian
}

\begin{abstract}
Teacher profession in Thailand are faced with pressure such as competition for student GPA, improving teaching efficiency, etc. To help teacher work effectively, school can focus on psychological factors. This paper aims to 1) examine the effect of job characteristic, social support, and work resilience on work passion and 2) examine the structure equation modeling of work passion of Thai teachers in municipal schools. 307 samples were Thai elementary teachers in municipal schools at Nakhon Si Thammarat province, Thailand. Data was collected by the questionnaires. The analytical statistics were mean, standard deviation, Pearson product moment correlation coefficient, and path analysis. It was found that the structure equation model of work passion was fitted with the empirical data $\left(\chi^{2} / d f=1.269, p\right.$-value $=0.053$, GFI $=$ 0.963, AGFI $=0.928$, Standardized RMR $=0.047$, RMSEA $=$ 0.030). Moreover, social support has a direct effect on work resilience, work resilience has a direct effect on work passion, and social support has both direct and indirect effect on work passion (through work resilience). But no significant effect of job characteristic on work passion. The model proposed that social support had the highest effect on work passion $(\beta=2.40, t$ = 5.27).
\end{abstract}

Index Terms-Job characteristic, social support, resilience, passion.

\section{INTRODUCTION}

Education is a key to develop the country as addressed by His Majesty the King on the occasion of the presentation ceremony of the Prince Mahidol awards in 1981. So far, Thai teachers (key factors in the educational system of the country) are faced with several problems that hinders the development of the youth of the country. These problem can clustered into two facets, 1) factors from teachers themselves (such as new generation teachers are lacking teaching spirit while older teachers hesitating to change, lack of autonomy) and 2) from external factors (for example: coworkers, school administrators, other workloads apart from teaching, insufficient number of teachers which forced teachers in municipal schools teach in another subject which are not his/her major) [1]. When asking the public about Thai teachers in the past 20 to 50 years, most of the answers discovered that Thai teachers in the past put their love,

Manuscript received June 5, 2015; revised August 25, 2015.

S. Lautongmeesakun is with the Department of Humanity, Faculty of Applied Art, King Mongkut's University of Technology North Bangkok, 1518 Pracharat 1 Road, Wongsawang, Bangsue, Bangkok, Thailand (e-mail: saitib@rocketmail.com).

S. Na Wichian is with the Department of Social and Applied Science, College of Industrial Technology, King Mongkut's University of Technology North Bangkok, 1518 Pracharat 1 Road, Wongsawang, Bangsue Bangkok 10800, Thailand (e-mail: sageemas@gmail.com). passion, soul and spirit in their job of being a teacher such as caring for students as if they were their own children, some of them even more devoted for their students than their family and private life. But when time changes, people's value change too. From article [2], it was discovered that modern family support was low for their children to become a teacher, as this profession had a low salary. Moreover, it found that many teachers lost passionate in their job, most of them focus on reporting their performance to compete with the other to get a better chance to promote. Teachers are evaluated in all sectors including [3]: working achievement motivation, service mind, self-development, teacher's ethics and integrity, team work, curriculum and learning management, classroom management, analysis \& synthesis \& classroom research, etc. which lead good or wise university students do not become teachers. Article [4] stated that factor affecting Thai teacher spirit and passion is the educational administration that crushing teachers to surrender for survive such as they have to give up their right for autonomy which affect their teaching of freedom. In addition, Thai's conservative concept of "Teachers are the second parents" that provides tight integration of power between critical parent and nurturing parent prohibited students who are in the position of children to speak out their argument (in Thai culture, children can't argue their parent because it's a sign of irreverence and violated folkways). Consequently, the effect is that no freedom of a thought system and less development.

The interesting reason from Tucker [5] about passion for work were: passion helps to engage an organization (when people discover the work that they love, work becomes a life's mission), people with passion for their work engage each other and their customers. Furthermore, Fried [6] stated that the genuine enthusiasm that passionate teachers express in their work can motivate students and focus the attention of administrators and parents on student learning as the highest educational priority. Thus, finding factors that affect the work passion of Thai teachers and their relationship is a key issue in this research. Work passion in this research refers to the behavior and intention to work. This factor considers five dimensions, using data from interviews and Zigarmi et al. concept as a base for research and then used the Exploratory Factor Analysis (EFA) method to classify the work passion's dimension that were 1) passion for organization (intention to stay as long as possible, enthusiasm and desire to perform for the school with full capability), 2) passion for duty (means responsible, enthusiasm and desire to work as a teacher with full capability, effective, and discreet), 3) passion for growth (means create new technique for career development, utilize multiple knowledge in teaching, discuss with school members, willing to recommend their own school to others), 4) passion 
for profession (profession endorsement, confidence of being a teacher, proud of being a teacher and appreciate profession that is an important and necessary to community).

The literature review found an effect from job characteristic on passion. Studies [7]-[13] concluded that job characteristics were the antecedents of passion. Moreover, Soralum [14] found that social support affecting work passion in cross generations. Connectedness with colleagues, recognition, meaningful work and autonomy could predict the work passion with all personnel's ability to 59.1 percent. The definition of job characteristic was based on Hackman and Oldham theory. Job characteristic refers to work's core that impacts teacher's motivation and good performance. The core dimensions are: skill variety (the degree to which a job requires various activities, requiring the teacher to develop a variety of skills and talents), task identity (the degree to which the job requires the teacher to identify and complete a work-piece with a visible outcome), task significance (the degree to which the job impacts teacher's lives, the influence can be either in the immediate school or in the external environment), autonomy (the degree to which the job provides the teacher with significant freedom, independence, and discretion to plan out the work and determine the procedures in the job), and feedback (the degree to which the teacher is provided with clear detailed information about the effectiveness of his or her job performance).

For variety of reasons, social support leads to many outcomes such as effectiveness, friendship, cohesion, performance, communication [15]-[18]. This research aimed to examine teacher's perceived social support and utilized the social support containing five dimensions based on Forsyth concept [19] including: 1) belonging (inclusion in a group), 2) emotional support (obtaining caring and concern for one another), 3) informational support (obtaining advice and guidance), 4) instrumental support (obtaining tangible resource), 5) spiritual support (addressing issues of meaning and purpose). A survey of employee passion found that social support (such as sharing experiences, supporting colleagues, free counseling) help pass on the passion, increased number of volunteers, higher participation rate, fosters their personal and professional development [20]. In addition, other research found that support helps create passion in the workplace [21]-[23]. Code of Conduct in The Teachers Council of Thailand's Regulation stated that the teacher must act in accordance with morals and ethics of profession in The Code of Conduct which including five area as follows: to oneself, to profession, to client, to co-professions, and to community. This Code of Conduct details are similar to social support [24].

Moreover, work resilience is one of the factor that affects work passion. Researchers use data from interviews and concept from several academics [25]-[27] then classify work resilience into three facets by the EFA method: 1) breakthrough (ability to manage work in hand to cross all problem), 2) well-dealing (ability to dealing with difficulty, good negotiator, good presenter), 3) bounce back (ability to recovery or adjustment after experiencing problem, not give up, looking forward to the next opportunity to act again). Fisher [28] found a relationship between resilience and passion, total effect of resilience on passion is 14 percent, significantly. Moreover, Day [29] found a positive correlation between social support and resilience. Moreover, Maturapodpong [30] indicated a negative relationship result.

The purpose of this research were

1) To examine the effect of job characteristic, social support, and work resilience on work passion of Thai teacher in Municipal Schools, and

2) To examine the structure equation model of work passion of Thai Teachers in Municipal Schools.

These research hypotheses are as follows:

Hypothesis 1 job characteristic, social support, and work resilience have direct effect on work passion.

Hypothesis 2 social support have direct effect on work resilience.

Hypothesis 3 social support have indirect effect on work passion through work resilience.

\section{METHOD}

\section{A. Data and Sample}

This research population was Thai teachers in municipal schools under Nakhon Si Thammarat Local Government Organization, Thialand. The sample size calculated with the $\mathrm{G}$ *Power program by setting as follows: test family $=\chi^{2}$, statistical test $=$ Goodness-of-fit tests: Contingency tables; Effect Size $=0.3, \alpha=0.05$, Power $=0.95, d f=5$. The minimum number of samples was 220 . Multi-stage sampling was applied starting from a purposive sampling to get municipal schools from 4 areas (Nakhon Si Thammarat Municipality, Tungsong Municipality, Pakpanang Municipality, and Nakhon Si Thammarat Provincial Administrative Organization) followed by the method of simple random sampling to obtain sample municipal schools. Subsequently, a targeted number of teachers were identified through convenience sampling. The number of returned completed questionnaires was 307.

\section{B. Measure}

The questionnaires survey was used to collect data. Before the questionnaires were administrated, they were pilot-test and validated.

Job characteristic, social support, work resilience, and work passion were assessed using a self-report, newly developed questionnaires base on a comprehensive literatures review and interviews data. Teachers were asked to respond to a four-point Likert scale ranging from 4 (absolutely true) to 1 (absolutely not true). In a total of 61 questions, questions 1 to 19 covered social support, for example, "my college praise me", "I can borrow private stuffs of my colleges". Questions 20 to 39 covered work passion, for example, "I would like to work in this school for as long as possible", "I'm proud of being a teacher". Questions 40 to 50 covered job characteristic, for example, "I finish my duty on time", "I have a freedom to make decision about my job". Questions 51 to 61 covered work resilience, for example, "I'll negotiate to get what I deserve", "I waited for an opportunity to perform again, when a previous attempt failed."

From pilot-test $(n=50)$, item-total correlation range from 0.358 to 0.729 and the Cronbach reliability alpha was 
relatively high (0.831 to 0.883$)$ confirming the relatively high reliability of this questionnaire.

\section{Statistical Analysis}

General information obtained from the survey such as sex, generation, education, tenure, and teaching subject were descriptively analyzed using simple frequencies and percentage. Mean and standardize deviation were used to descriptively assess the overall job characteristic, social support, work resilience, and work passion of the sample. Correlation between job characteristic, social support, work resilience, and work support was used as a basis to examine the causal relationship of each factor. Path analysis was conduct to identify the structure equation model. Guidelines for establishing acceptable fit were [31]-[33]: $\chi^{2} / d f$ should be less than $2.00, \mathrm{p}$-value should be greater than 0.05 , GFI and AGFI should be greater than 0.90, Standardized RMR should be less than 0.05 , RMSEA should be less than 0.08 .

\section{RESUlTS}

Most of participants were female (85 percent), Gen-X (53.7 percent), graduated with a bachelor's degree (79.5 percent), tenure (at the current school) under 10 years (45.6 percent), teach Math (19.5 percent). The average score of job characteristic was $3.42($ S.D. $=0.37)$, the average score of social support was 3.32 (S.D. $=0.39$ ), the average score of work resilience was $3.34($ S.D. $=0.40)$, and the average score of work passion were 3.58 (S.D. $=0.31)$.

TABLE I: THE CORRELATION COEFFICIENT OF CAUSAL VARIABLES AND OUTCOME VARIABLES

\begin{tabular}{lllll}
\hline \hline \multirow{2}{*}{ Variables } & \multicolumn{4}{c}{ Correlation coefficient } \\
\cline { 2 - 5 } & $\mathrm{JC}$ & $\mathrm{SS}$ & $\mathrm{RSL}$ & PASSION \\
\hline Job characteristic & 1 & & & \\
Social support & $0.543^{* *}$ & 1 & & \\
Work resilience & $0.648^{* *}$ & $0.397^{* *}$ & 1 & \\
Work passion & $0.569^{* *}$ & $0.513^{* *}$ & $0.481^{* *}$ & 1 \\
\hline \hline$* * p<0.01 ; n=307$ & & &
\end{tabular}

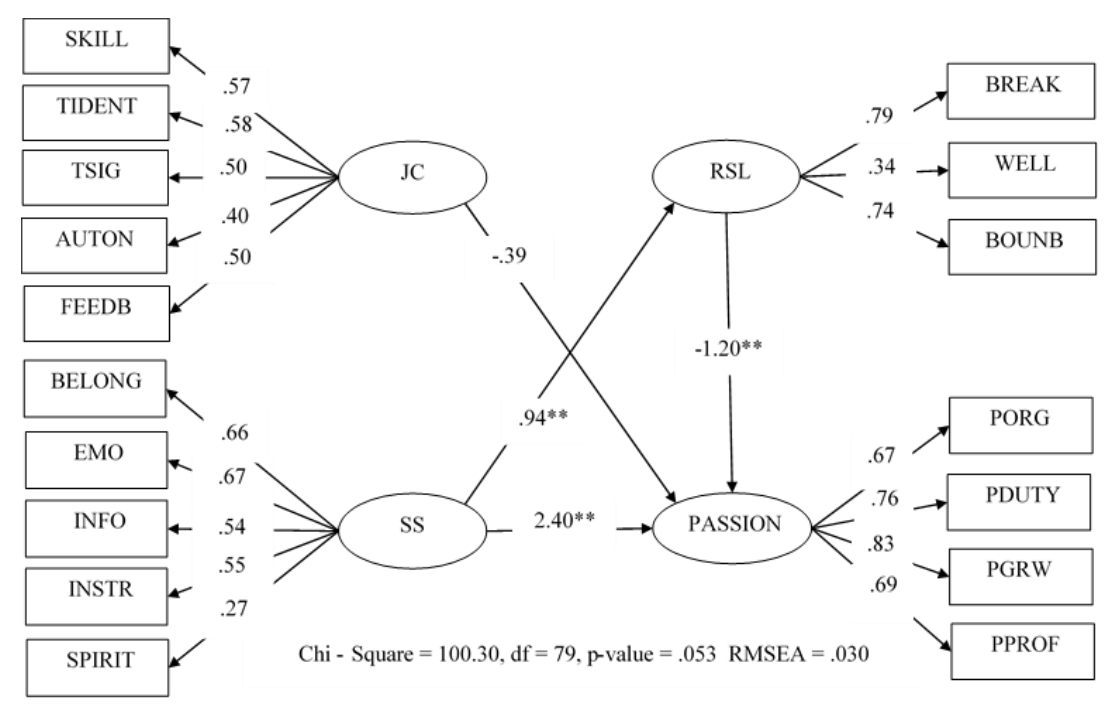

Fig. 1. Work passion model (final model) of Thai teachers in municipal schools.

In Table I, it can be noted that most of these variables were significantly positive correlate, range from 0.397 to 0.648 . The three most correlated variables were: job characteristic and work resilience $(r=0.648)$, job characteristic and work passion $(r=0.569)$, social support and work passion $(r=$ 0.513). According to Kline [34], this research correlation coefficient of overall variables were less than 0.85 refers to no multicollinearity.

The path analysis of work passion model (final model) of Thai teachers in municipal schools under Nakhon Si Thammarat Local Government Organization, Thialand, was fitted with the empirical data $\left(\chi^{2} / d f=1.269, p\right.$-value $=0.053$, GFI $=0.963$, AGFI $=0.928$, Standardized RMR $=0.047$, RMSEA $=0.030$ ).

Researchers concluded that the goodness of fit indices of this model is acceptable with model modification. Then continue to test Hypothesis 1 to 3, path analysis of work passion model of Thai teachers in municipal schools is presented (see Fig. 1 and Table II to Table III) as follows;

Hypothesis 1 focused on the direct of job characteristic, social support, and work resilience on work passion. As shown in Fig. 1, job characteristic) has no significant direct effect on work passion $(\beta=-.39, t=-.94)$. Nevertheless, social support $(\beta=2.40, t=5.27)$ and work resilience $(\beta=-1.20, t=$ -2.90) have significant direct effect on work passion, derived from emotional support (factor loading $=.67$ ), belonging (factor loading $=.66$ ), instrumental support (factor loading $=.55$ ), informational support (factor loading $=.54$ ), and spiritual support (factor loading $=.27$ ), breakthrough (factor loading $=.79$ ), bounce back (factor loading $=.74$ ), well-dealing (factor loading $=.34$ ), respectively. The finding partially supported the first hypothesis, social support, and work resilience has direct effect on work passion (see Fig. 1 and Table II).

Hypothesis 2 concern the direct effect of social support on work resilience. As shown in Fig. 1, social support has significant direct effect on work resilience $(\beta=.94, t=13.90)$, derived from emotional support (factor loading $=.67$ ), belonging (factor loading $=.66$ ), instrumental support (factor loading $=.55)$, informational support (factor loading $=.54$ ), and spiritual support (factor loading $=.27$ ), respectively. The result supported second hypothesis, social support have direct effect on work resilience (see Fig. 1 and Table II).

The result in Fig. 1 and Table III showed that the causal variable which has significantly highest total effect on work passion was social support $(\beta=.94, t=13.90)$. Overall, 
social support variable can be explained as the variation in work resilience 88 percent $\left(\mathrm{R}^{2}=.88\right)$. The social support and work resilience variable together can be explained the variation in work passion 100 percent $\left(\mathrm{R}^{2}=1.00\right)$

TABLE II: ACRONYM LIST FOR WORK PASSION MODEL

\begin{tabular}{ll}
\hline \hline Acronym & Variable's full name \\
\hline SKILL & Skill Variety \\
TIDENT & Task Identity \\
TSIG & Task Significance \\
AUTON & Autonomy \\
FEEDB & Feedback \\
BELONG & Belonging \\
EMO & Emotional support \\
INFO & Informational support \\
INSTR & Instrumental support \\
SPIRIT & Spiritual support \\
BREAK & Breakthrough \\
WELL & Well-dealing \\
BOUNB & Bounce back \\
PORG & Passion for Organization \\
PDUTY & Passion for Duty \\
PGRW & Passion for Growth \\
PPROF & Passion for Profession \\
\hline \hline
\end{tabular}

TABLE III: DIRECT, INDIRECT AND TOTAL EFFECT OF STRUCTURE EQUATION MODEL OF WORK PASSION OF THAI TEACHERS IN MUNICIPAL SCHOOLS

\begin{tabular}{llcc}
\hline \hline \multirow{2}{*}{ Causal Variables } & \multicolumn{2}{c}{ Effect } & \multicolumn{2}{c}{ Outcome variable } \\
\cline { 3 - 4 } & & RSL & PASSION \\
\hline Job characteristic & Direct & - & -0.39 \\
& Indirect & - & - \\
& Total & - & -0.39 \\
Social support & Direct & $0.94^{* *}$ & $2.40^{* *}$ \\
& Indirect & - & $-1.13^{* *}$ \\
Work resilience & Total & $0.94^{* *}$ & $1.27^{* *}$ \\
& Direct & - & $-1.20^{* *}$ \\
& Indirect & - & - \\
& Total & - & $-1.20^{* *}$ \\
$R^{2}$ & & 0.88 & 1.00 \\
\hline \hline$* * p<.01$ & & &
\end{tabular}

Hypothesis 3 focused on the indirect effect of social support on work passion through work resilience. As shown in Table II, social support has significant indirect effect on work passion through work resilience $(\beta=-1.13, t=-2.80)$. The result supported third hypothesis, social support have indirect effect on work passion through work resilience.

\section{CONCLUSION}

The focus of this research were 1) to examine the effect of job characteristic, social support, and work resilience on work passion of Thai teacher in Municipal Schools, and 2) to examine the structure equation model of work passion of Thai Teachers in Municipal Schools. The results demonstrated that the level of job characteristic, social support, work resilience, and work passion were high. The structure equation model of work passion of Thai Teachers in Municipal Schools was fitted with the empirical data with model modification as a result of the goodness of fit indices of this model are acceptable. The result of path analysis supported partly of hypothesis one: social support, and work resilience have direct effect on work passion, supported hypothesis two: social support have direct effect on work resilience, finally supported hypothesis three: social support have indirect effect on work passion through work resilience. These finding implied job characteristic is not necessary in building work passion of Thai Teachers in Municipal Schools, although there was a sign of effect but it was not significant. Social support and work resilience surely affected work passion of Thai Teachers in Municipal Schools. If teacher's perceived less social support, then it would impact teacher's work resilience and work passion such as ability to recovery or adjustment after experiencing problem, intention to stay as long as possible, enthusiasm and desire to perform for the school with full capability, and then particularly relevant to students and schools.

\section{DISCUSSION}

The result are in line with the report from [7]-[14], [21]-[24], [28]-[30] that 1) social support and work resilience have direct effect on work passion, and 2) social support has indirect effect on work passion through work resilience. In contrast, the job characteristic variable has no significant effect on work passion of Thai Teachers in Municipal Schools. This phenomenon may implied that work passion of Thai Teachers in Municipal Schools was more impacted by what they perceived supports from school member than school environment or job characteristic variable. The more the teacher received support, the more they tend to work with passion and resiliency. In previous phase of this study, researchers conduct an interview and found that most of key informants with high level of work passion stated that the school administration hinder them from doing a better performance such as paper works, work load, one teacher have to teach and do several task in school, but what make they not quit their job and continue being a teacher were supports they get from members in school, support from student's parent, and most of all they do their best for student's profit. This finding is inspiring researchers to facilitate a training program which promote teacher's work passion in the next phase.

From the result that indicated effect from social support on work resilience and work passion, school administrators or municipal should address social support (belonging, emotional support, informational support, instrumental support, and spiritual support) to promote teacher's passion and resilience. For example; inviting a more collaboration activities in school, using the brainstorm technique in school's staff meeting or small group weekly meeting, using positive reinforcement to those who provide support to others.

\section{REFERENCES}

[1] Saisapai, "6 problems of Thai teacher," Matichon, p. 7, January 22, 2013.

[2] ASTV. (March 28, 2012). Fake or fact: New GENs want to become a teacher. [Online]. Available: http://manager.co.th/Daily/ViewNews.aspx?NewsID=954000003926 0

[3] Office of the Basic Eucation Commission, Teacher's Competency Assessment Manual, Bangkok: Office of The Basic Eucation Commission, 2010. pp. 1-15.

[4] A. Pataradajapaisan. (December 30, 2011). Teacher's spirit in Thai society. Siamrath. [Online]. Available: http://www.oknation.net/blog/insanetheater/2011/12/31/entry-1 
[5] K. A. Tucker. (February 2012). A passion for work. Business Journal. [Online]. Available: http://www.gallup.com/businessjournal/379/passion-work.aspx

[6] R. L. Fried, The Passionate Teacher: A Practical Guide, Boston: Beacon Press, 2001, pp. 99-100.

[7] D. Zigarmi, K. Nimon, D. Houson, D. Witt, and J. Diehl. (2009). From engagement to work passion. [Online]. pp. 1-11 Available: http://www.kenblanchard.com/img/pub/Blanchard_From_Engageme nt_to_Work_Passion.pdf

[8] D. Zigarmi, K. Nimon, D. Houson, D. Witt, and J. Diehl. (2011). Employee work passion. [Online]. pp. 1-3. Available: www.kenblanchard.com/img/pub/Blanchard_Employee_Passion_Vol 4.pdf

[9] J. H. M. Joubert, "Job characteristics, engagement, burnout and organizational commitment of management staff at a platinum mine in the North-West Province,” M.Com, thesis. Dept. Industrial Psychology, North-West Univ., Potchefstroom, South Africa, 2005.

[10] H. Obi-Nwosu, J. A. O. Chiamaka, and O. M. Tochukwu, "Job characteristics as predictors of organizational commitment among private sector workers in Anambra State, Nigeria," International Journal of Asian Social Science, vol. 3, no. 2, pp. 482-491, 2013.

[11] F. M. Kangure, W. Guyo, and R. Odhiambo, "Relationship between job characteristics and employee engagement among state corporattions in Kenya," International Journal of Innovative Research \& Studies, vol. 3, no. 5, pp. 326-350, 2014.

[12] W. S. Lee, "The relationship between job characteristics and job satisfaction toward affective commitment: The case of engineers in Sapakat Setia Perunding SDN BHD," MBA thesis, School of management, Universiti Sains Malaysia, George Town, Malaysia, 2010 .

[13] A. B. Ozturka, M. Hancerb, and J. Y. Im, "Job characteristics, job satisfaction, and organizational commitment for hotel workers in Turkey," Journal of Hospitality Marketing \& Management, vol. 23, no. 3, pp. 291-313, 2014.

[14] D. Soralum, "A comparative study factors affecting work passion in cross generation: Case study of the Cement Thai (Keang Koi) Co, Ltd," M.Sc. dissertation, Dept. Human resource development, National Institute of Development Administration, Bangkok, Thailand, 2012.

[15] P. M. Blau, Exchange and Power in Social Life, New York: Wiley, 1964 , p. 62.

[16] A. Drach-Zahavy and A. Somech. (August 2000). Team heterogeneity and its relationship with team support and team effectiveness. Journal of Educational Administration. [Online]. 40(1). pp. 44-66. Available: http://www.emeraldinsight.com_Insight_ViewContentServlet_content Type=Article\&Filename=_published_emeraldfulltextarticle_pdf_074 0400103.pdf

[17] A. Kreitner and A Kiniki, Organizational Behavior, 8th ed., Boston: McGraw-Hill Irwin, 2008, pp. 558-559.

[18] S. E. Taylor, Health Psychology, 7th ed., New York: McGraw-Hill, 2009. pp. 145-171.

[19] D. R. Forsyth, Group Dynamics, 3rd ed., California: Brooks/Cole Wadsworth, 1999, pp. 100-103.

[20] Deutsche Bank. Global Survey on Employee Engagement 2013. [Online]. Available: https://www.db.com/cr/en/our-people/employeeengagement.htm

[21] G. A. Mangeau, R. J. Vallerand, J. Charest, S. Salvy, N. Lacaille, T. Bouffard, and R. Koestner. (2009). On the development of harmonious and obsessive passion: The role of autonomy support, activity specialization, and identification with the activity. [Online] Available: www.er.uqam.ca/nobel/r26710/LRCS/papers/mageau2009.pdf
[22] N. Othman and A. M. Nasurdin, "Social support and work engagement: A study of Malaysian nurses," Journal of Nursing Management, vol. 21, no. 8, pp. 1083-1090, 2012.

[23] W. C. Marcinkus, K. S. Whelan-Berry, and J. R. Gordon, "The relationship of social support to the work - Family balance and work outcomes of midlife women," Women in Management Review, vol. 22, no. 2 , pp. 86-111, 2007

[24] Royal Thai Government Gazette, The Code of Conduct for Thai teacher B.E.2556, 2013, pp. 73-74.

[25] F. Luthans, C. M. Youssef, and B. J. Avolio, Psychological Capital: Developing the Human Competitive Edge, New York: Oxford University Press, 2007

[26] C. Matta. (February 2013). 4 strategies to help you bounce back from adversity. [Online]. Available: http://psychcentral.com/blog/archives/2013/01/20/4-strategies-to-help -you-to-bounce-back-from-adversity

[27] M. Dent. (March 2013). Really surviving life: Real resilience and passion. [Online]. Available: http://www.maggiedent.com/content/really-surviving-life-real-resilien ce-and-passion

[28] R. Fisher, "Passion, resilience, obsession \& sustained entrepreneurial action: The path to entrepreneurial success," Ph.D. dissertation, Faculty of Business and Enterprise, Swinburne University of Technology, Victoria, Australia, 2011.

[29] A. Day. (2006). The power of social support: Mentoring and resilience. [Online]. Available: http://conversation.lausanne.org/uploads/resources/files/783/RES007 _The_Power_of_Social_Support_Mentoring_and_Resilience.pdf

[30] S. Maturapodpong, "Hope, optimism, and resilience as predictors of performance, job saicfaction, work hapiness, and organizational commitment," M.A. thesis, Dept. Psychology, Chulalongkorn Univ., Bangkok, Thailand, 2012.

[31] S. Angsuchoti, S. Wijitwanns, and R. Pinyopanuwat, Statistical Analysis for Social Science and Behavioral Science Research: Application for LISREL, Bangkok: Mission media, 2008. pp. 22-24.

[32] A. Diamantopoulos and J. Siguaw, Introduction to SEM, 2012, pp. 33-35.

[33] K. G. Jöreskog and D. Sörbom, Introduction to SEM, 2012, pp. 33-35.

[34] R. B. Kline, Principles and Practice of Structural Equation Modeling, New York: Guilford Press, 2005, p. 50.

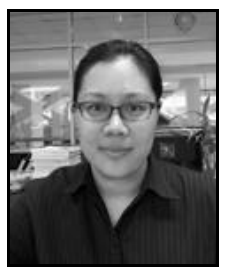

Saitib Lautongmeesakun was born at Nakhon $\mathrm{Si}$ Thammarat, Thailand, on March 12, 1985. She graduated with the bachelor of science degree in psychology from Burapha University, Chonburi, Thailand, in 2006. In 2010, she graduated with the bachelor of public health degree in occupational health and safety from Sukhothai Thammathirat Open University, Thailand. Then, she graduated with the master of science degree in industrial and organizational psychology from Kasetsart University, Thailand in 2012. Now, she is a Ph.D. candidate in industrial and organizational psychology, at King Mongkut's University of Technology North Bangkok, Thailand.

She is currently working as a lecturer in a Faculty of Applied Arts, King Mongkut's University of Technology North Bangkok, 1518 Pracharat 1 Road,Wongsawang, Bangsue, Bangkok 10800. She had a part-time job as a research assistant since 2009. 